\title{
Quality traits of raw and cooked cupped oysters
}

\author{
A. Felici ${ }^{1}$ S. Vittori $^{2}$ - M. C. T. Meligrana ${ }^{1} \cdot$ Alessandra Roncarati $^{1}$
}

Received: 31 January 2019 / Accepted: 21 July 2019 / Published online: 5 August 2019

(c) The Author(s) 2019, corrected publication 2019

\begin{abstract}
Proximate composition and fatty acid profile of raw cupped oysters (RA) were compared to conspecific submitted to two different cooking preparations (SA: cooking using extra virgin olive oil in a pan; GR: "gratin"). Moister content was significantly higher in RA $(81.7 \%)$ with respect to SA $(81.1 \%)$ and GR (81\%). Protein rate significantly decreased from RA $(8.8 \%)$ to SA $(8.3 \%)$ and GR (8.4\%). Lipids significantly increased in the two cooked GR $(2.8 \%)$ and SA (2.7\%) with respect to RA $(2 \%)$. Ashes ranged from GR $(1.98 \%)$ to RA (2\%). In the two cooking methods, 18:0 was significantly higher (GR $6.99 \%$ and SA $6.15 \%$ ) than in the raw oysters (RA 4.87\%). C18:1 was largely doubled in GR (14.43\%) and SA (13.77\%) with respect to RA (6.81\%). Among n-3 PUFA, 22:6 showed the highest percentage in all the three samples with a significant decrease passing from RA (21.39\%) to SA (18.45\%) and GR (17.95\%). 20:5n-3 had the highest content in RA (17.53\%) and significantly decreases in SA (14.09\%) and GR (14.54\%). Considering the trend of n-3 PUFA and n-6 PUFA, the n-3/n-6 ratio significantly decreased from RA (5.33) to SA (3.58) and GR (3.29). Although proximate composition and fatty acid profile changed after the cooking process, as consequence of the heat treatment and extra virgin olive oil added to the plates, the culinary preparations did not negatively compromise the quality traits of the cooked and gratin oysters.
\end{abstract}

Keywords Cupped oyster $\cdot$ Cooking process $\cdot$ Proximate composition $\cdot$ Fatty acid profile $\cdot$ Sensory attributes

\section{Introduction}

In Italy, the rearing of cupped oyster (Crassostrea gigas) started with mariculture techniques about 25 years ago, together with the autochthonous flat oyster species (Ostrea edulis). Evaluating the Italian oyster production in 2016, an increase of $+379.7 \%$ can be appreciated, passing from 53 to 254 tonnes of product placed on the market. However, the domestic annual demand is about 10,000 tonnes, mainly imported from France, Spain and The Netherlands. In the Adriatic Sea, the long-line practise has been implemented for both cupped oyster (Crassostrea gigas) and flat oyster

This manuscript is based on a contribution given at CHIMALI 2018, Italian Food Chemistry Congress, Camerino, September 24-27 2018.

Alessandra Roncarati

alessandra.roncarati@unicam.it

1 School of Biosciences and Veterinary Medicine, University of Camerino, Viale Circonvallazione 93-95, 62024 Matelica, Italy

2 School of Pharmacy, University of Camerino, Camerino, Italy
(Ostrea edulis) with the aim to diversify the shellfish production [1].

Among seafood, oysters were considered a luxury food although, more recently, their consumption is more related to special events and anniversaries. At international level, oysters are largely appreciated as raw with guaranteed freshness and sanitary parameters, but in the American and Asiatic countries, they are also eaten when subjected to several cooking procedures as baked, steamed, grilled, fried, canned or "in omelette". Some culinary experts consider the oysters to be "the easiest or the most difficult seafood" to consume. In Mediterranean countries, many events are organised and different culinary preparations are purposed to let people know the added value of cooked oysters. Recent papers, concerning the consumption of this bivalve, investigated the product packaging format, the nutritional knowledge and preferences of young and old people. The authors concluded that young people prefered to eat cooked oysters respect to the raw product [2-5].

In the bivalves, oysters included, the information in nutritional value primarily concerns the quality traits related to preserve microbial contamination and shelf-life $[6,7]$. Despite worldwide distribution and high commercial 
importance of oysters, information about different cooking methods of the cupped oysters remains limited and concerns mussels [8, 9], scallops [10] and clams [11].

To give a contribution to the knowledge of quality traits of the cupped oyster in different food preparations, a study was performed considering two culinary treatments: cooking, using free oil in pan, and "gratin". "Gratin" is a term that derives from the French language and is used to indicate the cooking method for baking food in the oven so as to obtain a thin and crunchy crust on the surface. The effects of the cooking preparations were evaluated on proximate composition and fatty acid profile of cupped oysters farmed in shellfish plant of the Adriatic mid coast. Sensory analyse was also performed by a panel test. The attributes were compared with raw fresh oysters of the same mean weight and provenience.

\section{Materials and methods}

\section{Sample preparation}

Ninety cupped oysters were collected from a long-line shellfish plant, located $5.5 \mathrm{~km}$ from the coast of Porto Recanati $\left(43^{\circ} 26^{\prime} 42.76^{\prime \prime} \mathrm{N}-13^{\circ} 43^{\prime} 45.33^{\prime \prime}\right)$, and stored in containers with ice to be transported to the laboratories of UNICAM for processing. The oysters were weighed individually $(65 \pm 2.5 \mathrm{~g})$, opened with a sharp knife-oyster inserted between the shells and removed cutting the adductor muscle, washed with running water and drained by adsorbent paper. Then, they were divided into three groups subjected to different culinary preparation: raw (RA, as Control, 30 animals), cooked (SA, 30 animals) and "gratin" (GR, 30 animals). RA oysters were used as traditionally served in their one-shell with their juice, just opened for raw assessment. The two groups of oysters to cook were removed from their shells. SA oysters were prepared cooking the oysters in olive oil with garlic, parsley and salt for $4 \mathrm{~min}$. Professional pans were used. GR oysters were obtained covering with salted chopped bread with olive oil, scallions and parsley. In "gratin", the cooking process was used to achieve the effect that is reached when a food is cooked at $170{ }^{\circ} \mathrm{C}$ for 5 min, in an electric oven, preheated at $250{ }^{\circ} \mathrm{C}$. Samples were homogenised with a blender and stored at $-20^{\circ} \mathrm{C}$ until further analysis. After cooking, SA and GR samples were placed for 3 min on absorbent paper towels.

\section{Proximate composition and fatty acid profile}

The chemical analysis of the three samples was performed according to the Association of Official Analytical Chemists procedure [12] (AOAC, 1990). Total lipid content was determined using the procedure described by Folch et al.
[13]. After determining total lipid content, fatty acids were converted into methyl esters following the method described by Christopherson and Glass [14]. The separation of fatty acids was carried out using a GC 3800 gas chromatograph (Varian Strumentazione, Cernusco sul Naviglio, Italy) with a WP-4 Shimadzu integration system (Shimadzu Corporation, Tokyo, Japan), which was equipped with a Supelco SPTM2340 capillary column $(30 \mathrm{~m} \times 0.25 \mathrm{~mm}$ i.d.; $0.25 \mu \mathrm{m}$ film thickness; Supelco, Bellefonte, Pennsylvania, USA) and a flame ionisation detector.

\section{Sensory analysis}

After the cooking preparation, sensory analysis was performed using samples from the three types of preparations submitted to twenty panellists ( 12 men and 8 women). They recorded the score on a grid with different attributes to measure differences in flavour, texture and preference. To compare the three dishes of oysters, sensory descriptors concerning saltiness, sweetness, acidity, tenderness, chewiness and texture were used.

\section{Statistics}

Data were submitted to one-way analysis of variance (ANOVA) using the General Model procedure of SPSS [15]. Differences were considered significant at $P<0.05$ and means were separated by Student Newmann Keuls test.

\section{Results}

The proximate composition of the oyster samples in relation to the three culinary preparation is reported in Table 1 . The moister content showed slight, but significant, differences between RA group (81.72\%) and SA (81.11\%) and GR sample $(81.04 \%)$. The protein rate significantly varied decreasing from the raw oysters (RA 8.85\%) to the cooked samples (SA $8.33 \%$ and GR 8.37\%). The lipid content exhibited a significant increase in the two cooked oysters (GR 2.80\% and SA $2.68 \%$ ) with respect to RA (2.05\%). Ash content ranged from GR group (1.98\%) to RA (2.04\%) sample without notable differences among the groups.

Table 1 Chemical composition of meat of cupped oyster analysed after the different culinary preparations

\begin{tabular}{lccc}
\hline & RA & SA & GR \\
\hline Moisture (\%) & $81.72 \pm 0.1 \mathrm{a}$ & $81.11 \pm 0.2 \mathrm{~b}$ & $81.04 \pm 0.4 \mathrm{~b}$ \\
Protein (\% as it is) & $8.85 \pm 0.4 \mathrm{a}$ & $8.33 \pm 0.3 \mathrm{~b}$ & $8.37 \pm 0.2 \mathrm{~b}$ \\
Lipid (\% as it is) & $2.05 \pm 0.1 \mathrm{~b}$ & $2.68 \pm 0.3 \mathrm{a}$ & $2.80 \pm 0.2 \mathrm{a}$ \\
Ash (\% as it is) & $2.04 \pm 0.5$ & $1.95 \pm 0.4$ & $1.98 \pm 0.3$ \\
\hline
\end{tabular}

Letters $(\mathrm{a}, \mathrm{b})$ on the same line show significant differences $(P<0.05)$ 
The fatty acid profile of the three preparations is reported in Table 2. Palmitic acid (C16:0) was the most important saturated fatty acid (SFA) in all the three samples (20.14-20.98\%) without significant differences from the statistical point of view. Stearic acid (C18:0) was the second most representative SFA, significantly higher in the two cooking methods (GR 6.99\% and SA 6.15\%) than in the raw oysters (RA 4.87\%). Differently, the other five SFAs (C14, $\mathrm{C} 15, \mathrm{C} 17, \mathrm{C} 20, \mathrm{C} 24)$, although recorded in low proportions, showed significant reductions passing from RA to SA and GR. As consequence, the total of SFA resulted decreasing from the raw sample RA (31.12\%) to the two cooking preparations (GR 29.73\% and SA 28.42\%).

Among the monounsaturated fatty acids (MUFA), the most prevalent was oleic acid (C18:1) with proportions largely doubled in GR (14.43\%) and SA (13.77\%)

Table 2 Fatty acid profile (\% of total fatty acids) of the three samples of cupped oyster submitted to different culinary preparations

\begin{tabular}{lccc}
\hline & RA & SA & GR \\
\hline C 14:0 & $2.07 \pm 0.02 \mathrm{a}$ & $0.31 \pm 0.01 \mathrm{~b}$ & $0.36 \pm 0.01 \mathrm{~b}$ \\
C 15:0 & $0.27 \pm 0.01 \mathrm{a}$ & $0.16 \pm 0.02 \mathrm{~b}$ & $0.12 \pm 0.03 \mathrm{~b}$ \\
C 16:0 & $20.50 \pm 0.60$ & $20.14 \pm 0.60$ & $20.58 \pm 0.70$ \\
C 17:0 & $1.84 \pm 0.04 \mathrm{a}$ & $1.66 \pm 0.05 \mathrm{~b}$ & $1.68 \pm 0.03 \mathrm{~b}$ \\
C 18:0 & $4.87 \pm 0.40 \mathrm{~b}$ & $6.15 \pm 0.80 \mathrm{a}$ & $6.99 \pm 0.90 \mathrm{a}$ \\
C 20:0 & $1.12 \pm 0.01 \mathrm{a}$ & $0.00 \pm 0.00 \mathrm{~b}$ & $0.00 \pm 0.00 \mathrm{~b}$ \\
C 24:0 & $0.45 \pm 0.02 \mathrm{a}$ & $0.00 \pm 0.00 \mathrm{~b}$ & $0.00 \pm 0.00 \mathrm{~b}$ \\
Total saturated & $31.12 \pm 0.13 \mathrm{a}$ & $28.42 \pm 0.17 \mathrm{~b}$ & $29.73 \pm 0.19 \mathrm{~b}$ \\
C 16:1 & $2.28 \pm 0.05 \mathrm{~b}$ & $4.50 \pm 0.04 \mathrm{a}$ & $2.32 \pm 0.03 \mathrm{~b}$ \\
C 17:1 & $1.16 \pm 0.01 \mathrm{a}$ & $0.00 \pm 0.00 \mathrm{~b}$ & $0.00 \pm 0.00 \mathrm{~b}$ \\
C 18:1 & $6.81 \pm 0.80 \mathrm{~b}$ & $13.77 \pm 0.60 \mathrm{a}$ & $14.43 \pm 0.95 \mathrm{a}$ \\
C 20:1 & $0.88 \pm 0.03$ & $1.00 \pm 0.03$ & $1.00 \pm 0.04$ \\
C 24:1 & $0.27 \pm 0.01$ & $0.00 \pm 0.00$ & $0.00 \pm 0.00$ \\
Total Monounsatu- & $11.40 \pm 0.11 \mathrm{~b}$ & $19.27 \pm 0.18 \mathrm{a}$ & $17.75 \pm 0.13 \mathrm{a}$ \\
rated & & & \\
C 18:3 n-3 & $5.02 \pm 0.03 \mathrm{c}$ & $6.42 \pm 0.04 \mathrm{a}$ & $6.20 \pm 0.03 \mathrm{~b}$ \\
C 18:4 n-3 & $2.89 \pm 0.02 \mathrm{a}$ & $1.10 \pm 0.05 \mathrm{~b}$ & $1.05 \pm 0.02 \mathrm{~b}$ \\
C 20:5 n3 & $17.53 \pm 0.45 \mathrm{a}$ & $14.09 \pm 0.56 \mathrm{~b}$ & $14.54 \pm 0.44 \mathrm{~b}$ \\
C 22:5 n-3 & $1.04 \pm 0.01 \mathrm{a}$ & $0.71 \pm 0.02 \mathrm{~b}$ & $0.21 \pm 0.02 \mathrm{c}$ \\
C 22:6 n-3 & $21.39 \pm 0.20 \mathrm{a}$ & $18.45 \pm 0.54 \mathrm{~b}$ & $17.95 \pm 0.60 \mathrm{~b}$ \\
Total PUFA n-3 & $47.87 \pm 0.14 \mathrm{a}$ & $40.77 \pm 0.24 \mathrm{~b}$ & $39.95 \pm 0.22 \mathrm{~b}$ \\
C 18:2 n-6 & $2.62 \pm 0.42 \mathrm{~b}$ & $8.12 \pm 0.57 \mathrm{a}$ & $9.92 \pm 0.62 \mathrm{a}$ \\
C 18:3 n-6 & $1.28 \pm 0.03 \mathrm{~b}$ & $2.23 \pm 0.02 \mathrm{a}$ & $1.23 \pm 0.04 \mathrm{~b}$ \\
C 20:3 n-6 & $1.20 \pm 0.02 \mathrm{a}$ & $0.00 \pm 0.00 \mathrm{~b}$ & $0.00 \pm 0.00 \mathrm{~b}$ \\
C 20:4 n-6 & $3.88 \pm 0.02 \mathrm{a}$ & $1.04 \pm 0.03 \mathrm{~b}$ & $1.00 \pm 0.02 \mathrm{~b}$ \\
Total PUFA n-6 & $8.98 \pm 0.47 \mathrm{~b}$ & $11.39 \pm 0.68 \mathrm{a}$ & $12.15 \pm 0.55 \mathrm{a}$ \\
Total PUFA & $56.85 \pm 0.11 \mathrm{a}$ & $52.16 \pm 0.17 \mathrm{~b}$ & $52.10 \pm 0.16 \mathrm{~b}$ \\
n-3/n-6 & $5.33 \pm 0.12 \mathrm{a}$ & $3.58 \pm 0.18 \mathrm{~b}$ & $3.29 \pm 0.14 \mathrm{~b}$ \\
Others* & $0.62 \pm 0.04$ & $0.15 \pm 0.01$ & $0.42 \pm 0.02$ \\
\hline & & & \\
\hline
\end{tabular}

Letters $(\mathrm{a}, \mathrm{b}, \mathrm{c})$ on the same line show significant differences $(P<0.05)$

*Not submitted to statistical analysis with respect to RA (6.81\%). Palmitoleic acid (C16:1) was the second most important MUFA and significant differences between SA (4.5\%) and RA (2.28\%) and GR $(2.32 \%)$ emerged. As a consequence of the trend of these fatty acids, total MUFA proportion was the highest in SA (19.27\%) in comparison with GR (17.75\%) and RA (11.40\%).

As regards polyenoic $n-3$ fatty acids, DHA (C22:6n-3) showed the highest percentage in all the three samples with a significant decrease passing from RA $(21.39 \%)$ to the two cooking treatments SA (18.45\%) and GR (17.95\%), not different between them. The trend of EPA (C20:5n-3) proportion was the same as DHA, showing the highest content in RA (17.53\%) and significantly decreases in SA (14.09\%) and GR (14.54\%). Total n-3 PUFA showed a remarkable reduction from RA to the two culinary procedures. Among the n-6 PUFA, arachidonic acid (C20:4 $\mathrm{n}-6)$ was significantly the prevalent in RA (3.88\%). On the contrary, linoleic acid (C18:2 n-6) was the highest in the two cooked samples where its proportion significantly showed an increase of 5.5\% and 6.3\% in SA and GR samples, respectively. Considering the trend of $n-3$ PUFA and n-6 PUFA, the n-3/n-6 ratio significantly decreased from RA (5.33) to SA (3.58) and GR (3.29).

In Fig. 1, the results of the panel test performed on the three groups of oysters were reported. No significant differences were detected excepted two descriptors of sweetness (GR) and tenderness (RA).

\section{Discussion}

In this study, the raw oysters showed a chemical composition in line with the proximate analysis of conspecific bivalves produced in the Adriatic sea, both in lagoon and in offshore condition [16,17], characterised by good

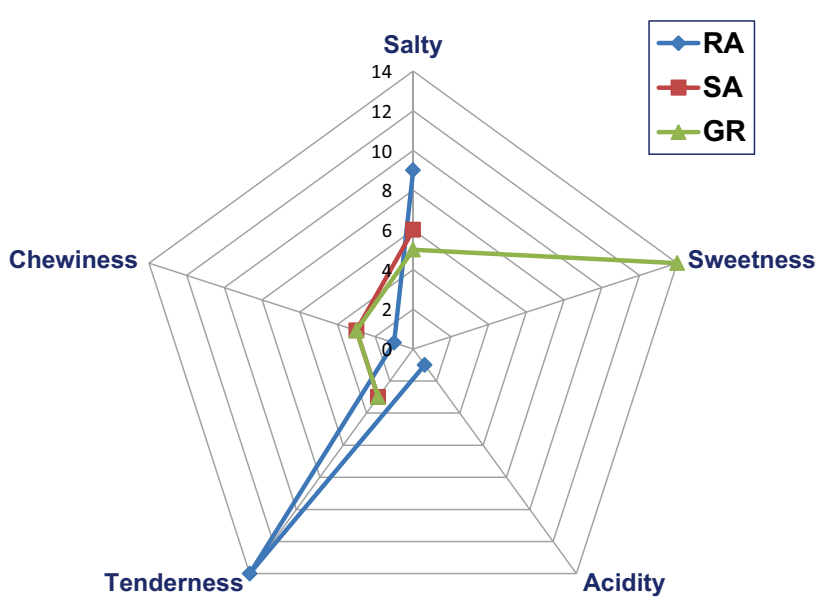

Fig. 1 Results of sensory evaluation of the three oyster samples 
protein level, low lipid content attesting the high quality value of oysters employed for the present trial.

In the two groups of oysters submitted to cooking process, as cooked (SA) and "gratin" (GR), the proximate composition and the fatty acid profile exhibited significant changes in moisture, protein and lipid content in both the culinary preparations. In our case, in both the cooked oysters, water evaporation was observed in a similar way, without effects of high dehydration as expected when the oven-cooking is employed [18]. In GR oysters, the "gratin" helped to produce the crust over oysters and avoided this effect. In the cooked preparations, the slight decrease of protein level and lipid increase were in agreement with several studies on cooking of seafood concerning the nutritional changes affected by temperature and cooking method. A review on the effects of processing technologies and preparation on the final quality of seafood [19] reported that cooking generally induces a decrease in moisture content and a corresponding increase in other macronutrients, as protein and lipid. In two of the most consumed fish species, as salmon and mackerel, Bastìas et al. [20] revealed that protein content significantly increased under the different cooking, based on heat process, in front of a significant moisture decrease and a lipid increase. In relation to the other bivalves, as in our study, also the Ark shell (Arca noae) showed an inverse relationship between water content and protein content after the cooking treatment in comparison with the raw mollusc, whereas lipids significantly decreased, excepted for the steamed cooking [21]. In relation to the kind of treatment and the lipid fraction, cooked oysters SA and GR exhibited a fat content higher than the raw ones, in full agreement with other authors [22] who considered method of cooking, like frying with immersion in oil, as crucial factor to affect the fat level of meat. However, in our study, after the cooking methods, the lipid increase did not compromise the quality of meat and oysters meat could be classified as "lean", being the fat content is lower than $3 \%$, that is the limit that discerns them from fatty seafood [23]. Moreover, the cooking methods we applied were characterised by a short time of exposure to heat, exposing the oysters to moderate temperature and homogeneity of temperature distribution was assured using professional devices for restaurant kitchen.

Concerning the fatty acid profile, the RA oysters also exhibited a very favourable fatty acid profile. The very high proportions of n-3 PUFA were in agreement with those reported by Pogoda et al. [24], in cupped oysters reared in the German North Sea, and Dridi et al. [25] in oysters in the north of Tunisia, considering the same season of the current study (Spring). Our data were ascertained that raw cupped oyster is a good source of n-3 PUFA; comparing this long series fatty acids of $C$. gigas to other fresh common bivalves, oysters had a fraction of this essential fatty acids higher than Mediterranean mussels (Mytilus galloprovincialis) where EPA and DHA were detected at $7.8 \%$ and $18.6 \%$ of total fatty acids, respectively [8].

In all the categories of fatty acids, the cooked oysters showed changes in comparison with the raw sample as result of the addition of extra virgin olive oil for cooking. The increased proportions of oleic acid and, a lesser extent, of stearic acid, may be the result of the influence of this vegetable oil, which is a rich source of these two fatty acids, as reported in a recently review about the biological properties of the extra virgin olive oil [26]. The use of this vegetable oil consequently determined an increase of the n-6 PUFA, linoleic acid, and a reduction of the most relevant n-3 PUFA reduced in both the cooked oysters. However, EPA and DHA still maintained satisfactory proportions with a favourable $n-3 / n-6$ ratio if compared to other cooking practices. It has been ascertained that the frying process determines changes in the amount of PUFA, both in fish and in molluscs $[21,27]$.

Concerning the panel test results for the sensory attributes, there were discrepancies in the assessment of some of the attributes by some panellists, both in raw and in "gratin"; however, all the preparations were judged highly tasty without compromising the nutritional properties.

These results showed that the cooking treatment and the addition of extra virgin olive oil affected the proximate composition and the fatty acid profile of the cooked oysters. However, in this trial, we used a short exposition to heat and modifications did not negatively compromise the quality traits of the cooked and "gratin" oysters. It can be concluded that the preparations considered in this study are appropriate for cupped oysters cooking.

Acknowledgements Research supported by FAR 2014-2018 "Improvement of quality traits of oysters (Crassostrea gigas, Ostrea edulis), reared in long-line plants and stored in closed circuit system (OYSTAR)", UNICAM. We are grateful to: the shellfish farm, BIVI srl Civitanova Marche, for providing the fresh oysters; the Professors of Hotel Management Schools of Buscemi (S. Benedetto del Tronto, AP, It) and Nebbia-Einstein (Loreto, AN, It) for their precious suggests about the receipts; Villa Fornari Relais for the technical assistance with cooking preparations; and students and friends assayers participating to the panel test.

\section{Compliance with ethical standards}

Conflict of interest The authors declare that there is no conflict of interest regarding the publication of this paper.

Compliance with ethics requirements All applicable international, national, and institutional guidelines for the care and use of animals were followed by the authors. 
Open Access This article is distributed under the terms of the Creative Commons Attribution 4.0 International License (http://creativeco mmons.org/licenses/by/4.0/), which permits unrestricted use, distribution, and reproduction in any medium, provided you give appropriate credit to the original author(s) and the source, provide a link to the Creative Commons license and indicate if changes were made.

\section{References}

1. Wijsman JWM, Troost K, Fang J, Roncarati A (2019) In: Smaal AC, Ferreira JG, Grant J, Petersen JK, Strand Ø (eds) Goods and services of marine bivalves. Springer Open. https://doi. org/10.1007/978-3-319-96776-9

2. Loose SM, Peschel A, Grebitus C (2013) Quantifying effects of convenience and product packaging on consumer preferences and market share of seafood products: the case of oysters. Food Qual Prefer 28:492-504

3. Masson E, Debucquet G, Fischler C, Merdji M (2016) French consumers' perceptions of nutrition and health claims: a psychosocial-anthropological approach. Appetite 105:618-629

4. Santeramo FG, Carlucci D, De Devitiis B, Nardone G, Viscecchia $\mathrm{R}$ (2017) On consumption patterns in oyster markets: the role of attitudes. Mar Policy 79:54-61

5. van Houcke J, van Dalen P, Bakhuizen W, Linssen J, Luten J (2018) Tailor-made seafood: oyster refinement as a tool of overcoming consumer barriers. In: Proc. Conference AQUA2018, Montpellier, 25-29 August 2018

6. Manita D, Alves RN, Braga AC, Fogaça FHS, Marques A, Costa PR (2017) In vitro bioaccessibility of the marine biotoxins okadaic acid, dinophysistoxin-2 and their 7-O-acyl fatty acid ester derivatives in raw and steamed shellfish. Food Chem Toxicol 101:121-127

7. Bongiorno T, Tulli F, Comi G, Sensidoni A, Andyanto D, Iacumin L (2018) Sous vide cook-chill mussel (Mytilus galloprovincialis): evaluation of chemical, microbiological and sensory quality during chilled storage $\left(3^{\circ} \mathrm{C}\right)$. LWT Food Sci Technol 91:117-124

8. Otles S, Sengor G (2005) Effect of various technological processes on the fatty acid composition of Mussel (Mytilus galloprovincialis, L.). Int J Food Eng 1:1-7

9. Zhou M, Balaban MO, Gupta S, Fletcher GC (2014) Comparison of lipid classes and fatty acid profiles of lipids from raw, steamed, and high-pressure-treated New Zealand greenshell mussel meat of different genders. J Shellf Res 33:473-479

10. Su XQ, Antonas KN, Li D (2004) Comparison of n-3 polyunsaturated fatty acid contents of wild and cultured Australian abalone. Int J Food Sci Nutr 55:149-154

11. Czech A, Grela ER, Ognik K (2015) Effect of frying on nutrients content and fatty acid composition of muscles of selected freezing seafood. J Food Nutr Res 3:9-14

12. AOAC (1990) Official methods of analysis, 15th edn. AOAC, Washington DC, USA

13. Folch J, Lees M, Sloane Stanley GH (1957) A simple method for the isolation and purification of total lipids from animal tissues. $J$ Biol Chem 226:497-509
14. Christopherson SW, Glass RL (1969) Preparation of milk methyl esters by alcoholysis in an essentially nonalcoholic solution. J Dairy Sci 52:1289-1290

15. IBM Corp Released (2017) IBM SPSS Statistics for Windows, Version 25.0. IBM Corp, Armonk

16. Orban E, Di Lena G, Masci M, Nevigato T, Casini I, Caproni R (2004) Growth, nutritional quality and safety of oysters (Crassostrea gigas) cultured in the lagoon of Venice (Italy). J Sci Food Agric 84:1929-1938

17. Roncarati A, Gennari L, Felici A, Melotti P (2012) Development of the oyster farming in the Middle Adriatic sea. Aquacult Europe 37:26-32

18. Koubaa A, Mihoubi NB, Abdelwaheh A, Bouain A (2012) Comparison of the effects of four cooking methods on fatty acid profiles and nutritional composition of red mullet (Mullus barbatus) muscle. Food Sci Biotechnol 21:1243-1250

19. Sampels S (2015) The effects of processing technologies and preparation on the final quality of fish products. Trends Food Sci Technol 44:131-146

20. Bastías JM, Balladares P, Acuña S, Quevedo R, Muñoz O (2017) Determining the effect of different cooking methods on the nutritional composition of salmon (Salmo salar) and chilean jack mackerel (Trachurus murphyi) fillets. PLOS One 1-10

21. Ghribi F, Bejaoui S, Rabeh I, Aouini F, Chetoui I, El Cfasi M (2017) Effects of culinary methods on nutritional characteristics of the edible shellfish Noah's Ark (Arca noae L., 1758) from Tunisian Coasts. J Aquat Food Prod Technol 26:1324-1336

22. Abraha B, Admassu H, Mahmud A, Tsighe N, Shui XW, Fang Y (2018) Effect of processing methods on nutritional and physicochemical composition of fish: a review. MOJ Food Process Technol 6:376-382

23. Greenfield H, Southgate DAT (2003) Food composition data. FAO, Rome. ISBN 9251049491

24. Pogoda B, Buck BH, Saborowski R, Hagen W (2013) Biochemical and elemental composition of the offshore-cultivated oysters Ostrea edulis and Crassostrea gigas. Aquaculture 400-401:53-60

25. Dridi S, Romdhane MS, El Cafsi M (2017) Nutritional quality in terms of lipid content and fatty acid composition of neutral and polar lipids in the adductor muscle of the oyster Crassostrea gigas (Thunberg, 1794) farmed in the Bizert lagoon (Tunisia) in relation with sexual cycle and environmental settings. Egypt $\mathbf{J}$ Aquat Res 43:329-336

26. Yubero-Serrano EM, Lopez-Moreno J, Gomez-Delgado F, LopezMiranda J (2018) Extra virgin olive oil: more than a healthy fat. Eur J Clin Nutr. https://doi.org/10.1038/s41430-018-0304-x

27. Schneedorferova I, Tomcala A, Valterova I (2015) Effect of heat treatmente on the n-3/n- 6 ratio and content of polyunsaturated fatty acids in fish tissues. Food Chem 176:205-211

Publisher's Note Springer Nature remains neutral with regard to jurisdictional claims in published maps and institutional affiliations. 